\title{
A JUDICIAL APPRAISAL ON THE BEST INTEREST OF THE CHILD STANDARD WITH REGARD TO CUSTODY AND ACCESS DECISIONS ON DIVORCE: A CONSTITUTIONAL DEVELOPMENTAL IMPRINT
}

\author{
Dr Nico P Swartz. \\ Faculty of Social Sciences, Department of Law, University of Botswana.
}

\begin{abstract}
This paper does not cover all aspects of court decisions about the interests of the child. It is confined to only the best interest of the child with regard to custody decisions on divorce in Botswana jurisdictions with an imprint of South African law dynamics. Everyone that is involved in the operation of an understanding of the child's situation will benefit from what is going to be discussed in this paper. This study, however, actuates much more research into the questions of the best interests of the child. The research purports the acquisition of knowledge necessary to map out the best interests of the child standard. It does so by stressing the obsolete nature and dysfunctional practice of relics of Roman-Dutch and English common law. The study paves a new direction for determination purposes of the best interests of the child in line with constitutional imperatives or values. The research drawn the theoretical modalities from other jurisdictions, but in its practical application it resort to the Botswana judicature. Case laws of Botswana in which a constitutional imprint could be detected are, for example, Ndlovu $v$ Macheme and Mokoti $v$ Okatswa to name but a few. The stage is set firmly now for the protection and upholding of the best interests of the child along constitutional lines.
\end{abstract}

\section{Keywords}

Child custody, patriarchy, divorce, husband and wife, household, civil and common law jurisdictions.

\section{Academic Discipline And Sub-Disciplines}

The study shows a strong penchant for Law; Psychology; Education in order to manifest the idea of the best interest of the child in societal norms.

\section{SUBJECT CLASSIFICATION}

The subject classification hinges upon a Library of Congress Classification.

\section{METHOD/APPROACH}

The study is a Theoretical Inquiry upon which the author draws his analysis and conclusions.

\section{INTRODUCTION}

\section{Historical Evaluation Of Child Custody Issues}

- The issue of child custody has been viewed since time immemorial through the lens of patriarchy. In the civil law tradition of Western Roman Empire, fathers were usually given custody of their children upon divorce. Women were not educated and they had no way to eked out a livelihood for themselves least to provide for their children materially. To add insult to injury, mothers were not even regarded as fit to care for their children. Fathers, on the other hand, had complete control over their children. This legal and social model capacitated the father with complete and absolute control and custody of their children. This standard has been maintained for centuries. ${ }^{1}$

- Women's abject status stemmed from the Roman Empire through to Medieval Europe. Because of their detrimental status, women were regarded as minors in societal and legal matters. A husband could easily obtain a divorce by either mutual agreement with his wife or by repudiation of his wife and still have a custody ruling in his favour. Fault on his part had not dismissed the husband from custody entitlement. It was his right automatically because the Latin adage refers to the husband as the head of the household (paterfamilias) with final authority over his wife and children. The inverse to the husband's capacity, is the wife's legally incapacity to exert the same entitlement and rights to that of her husband. ${ }^{2}$ This legal arrangement or standard reigned for

\footnotetext{
${ }^{1}$ Ruth Ann Wright, MA. 2009. The Best-Interest of the Child Variables in Custody Evaluations and their Usefulness to the Decision-Making of Custody Evaluators, Litigants, and Judges. A Dissertation submitted to Fielding Graduate University in partial fulfilment of the requirements for the degree of Doctor of Philosophy in Psychology. ProQest LLC, Parkway, United States: 1.

${ }^{2}$ Wright 2009: 2.

Swartz, Nico P. The Implications of Women's Late Entry to the Bar and Their Treason Against the Order of Nature: A Judicial Analysis. Journal of Scientific Research \& Reports (2016), 12(4): 1-13: 3.
} 
centuries under civil (Roman law and European countries) and even under common law jurisdictions until the $19^{\text {th }}$ century. ${ }^{3}$

This paper is, however, being confined to the civil and common law jurisdictions: There appears to be other jurisdictions as well, especially those of the East continents and Far East world, which evoke a totally different practice of law as the civil and common law traditions, dictated by the Western world. The study, therefore, excite other researchers all over the world to test the hypothesis of the best interests of the child reached in this research against non-Western traditions through a legal lens.

Under a historical portrayal of the English common law system, colonists were sent to all parts of the world to extend the British Empire. For example, English colonists who arrived in North America in the early 1600s, brought with them a legal figure, parens patriae. Parens patriae refers to the role of the state as sovereign authority over persons under legal disability, such as juveniles or the insane. This principle, designed for the public sphere is to be applied later onto the domestic sphere where custody arrangements (so) formed, is the order of the day. The role of the state in the public domain had been shift to that of the mother/wife in the private sphere when the mother is propelled to act and to protect the best interests of the child.

But, due to deviant mothers or wifes' (in the past) there was a need to abdicate the role of mothers to be taken up by an impartial institution, which is only concern with the principle of the best interests of the child. This institution, in taken up unto itself such an important mandate must enjoy the necessary legal authority to lay or stamp down its powers with regard to the best interests of the child in the community. The institution, we are talking about, is called the Court. The Court, in no means is going to usurp the mandate of the wife or mother as primary caretaker and nurturer before or after divorce. The Court's over-arching task with regard to the custody of children is always to consider the best interests of the child.

By reverting back in history and as stated earlier, custody arrangements always befell the father or husband, but centuries later a paradigm shift had been set in motion whereby mothers or wife's as natural primary care-givers were awarded custody of minor children with the father being responsible for the children's material support to the mother. Under a constitutional era clouded with human rights concerns of both sexual partners, the mother's claim for custody and access had been challenged as can be seen in the discussed case laws later in the text.

The private domain of the family had been moved now from obscurity to the public domain where the mother's and father's rights with regard to custody and access of minor children have to be weigh up against one another. In this assessment, the Courts determination hinges in favour of the party that will secure and maintain the best interests of the children. Sex/gender is long ago no more absolute factor that will have attracted a positive outcome of a custody hearing. Under this atmosphere and mind-set, the Court, therefore, regards itself as upper guardian of all minor children. The court's current authority to intervene in family matters such as the custody of children is rooted in this legal principle. The state or rather the Court has the responsibility to protect those who are unable to protect themselves. ${ }^{4}$

The $19^{\text {th }}$ century imbued with feminist influences and a penchant for liberal ideologies brought with it societal changes that militated against patriarchal notions. These societal changes have led to the establishment of the cult of motherhood, which was suppressed for centuries during the Roman Empire and even under Medieval periods. This cult elevated mother's status and proclaimed their superior ability to care for and nurture young children. With this shift in the social construct of parenthood, away from father's rights and responsibilities and toward mother's tender love, the law began to focus on a different aspect of the child's interests. The belief come to be inculcated in the hearts of humankind that mothers, not fathers, best met young children's interests. This cult of motherhood would have provided the social underpinnings for a maternal preference in custody determinations. ${ }^{5}$

In the 1960s and 1970s, social and political movements promoted civil rights, women's rights and children's rights. Legal figures such as the institution of marriage, the structure of the family, parental and gender encountered social changes. ${ }^{6}$ Women are allowed to engage in employment outside the domestic sphere and this would have triggered divorce issues. Parents now look up to the Courts for help in determining child custody arrangements. These motivations have pressed the courts to shift the legal focus from parent's rights to the best interests of the child.

Divorce and custody laws, however, do not avail criteria for determining the best interests of the child. Judges were left with a vague and indeterminate standard and little guidance as to how they should proceed. The best interests of the child criteria therefore remained unclear, undefined and unspecified. Bogged down by this inertia, the courts reached out to social scientists and mental health professionals for assistance in resolving the issues around best interests criteria of the child. This development in custody determinations were hallmarked by the involvement of expert witnesses such as psychologists, social workers and psychiatrists in Courts regarding the

\footnotetext{
${ }^{3}$ Swartz 2016: 4. Roman law became synonymous to civil law because of its originating feature in Europe. The core principles of civil law were that it derived from the Code of Justinian.

${ }^{4}$ Wright 2009: 2

${ }^{5}$ Wright 2009: 3.

${ }^{6}$ Wright 2009: 4.
} 
determinations of the best interests of the child. ${ }^{7}$ The Courts took note of these professional's reports in the custody decision-making process.

\section{PSYCHOLOGICAL PARENT MORE IMPORTANT THAN BIOLOGICAL PARENT}

Biological parenthood does not necessarily connote to a mother as the primary care-giver. She could have just birthed the child and abscond - leaving the child to another to take care off. For consideration of this information the child's best interests are to be located in what we call the psychological parent. The psychological parent does not need to be genetically related to the child. The primary psychological relationship is therefore regarded as more important than the biological relationship.

\section{STATUTE LAWS TO PROTECT THE RIGHTS OF THE CHILD}

Children were largely invisible before the 1980s. A conference, which underpinned children's movement, led to the enshrinement of children's rights in the 1994 Interim as well as the final Constitution of South Africa, Act 108 of 1996. The final constitution, which provisioned the values of the best interests of the child, comes to dubbed children as human rights beneficiaries. ${ }^{8}$

In South Africa's concern for the best interests of the child, the country became an important role player in international law and politics when its executive ratified UN Convention on the Rights of the Child in 1989 and in 1990 and subsequently domesticated the Convention on the Rights of the Child in $1995 .{ }^{9}$

The legal environment concerning children and their well-being also led to the establishment in 1990 of the Office of the Family Advocate. The Family Advocate's duties focus on the oversight of the interests of children in contested and uncontested divorce proceedings. ${ }^{10}$ The Family Advocate Office, a new invention of statute law, however, does not have the manpower, the skills and expertise to afford relative peace between two opposing parties for the sake of the children. It still needed the necessary logistics to map out its functions and mandate. This ineptitude of the Office had triggered the emergence of a commission of enquiry into children's best interests in parental disputes.

Such commission, entitled The Hoexter Commission, had expressed concern that there was not sufficiently thorough investigation of arrangements concerning children in divorce proceedings. Evidences before Court were usually presented only by the plaintiff, and the appointment of a legal representative for a child was a rarity. In the conflict situation created by the adversarial system that prevails in South Africa's civil law tradition, children's interests were frequently subordinated to those of their parents. ${ }^{11}$

As a result the legislature enacted the Mediation in Certain Divorce Matters Act (Act 24 of 1987). This Act directed that an office be set up, staffed by both social work and legal personnel, who would be able to represent children's interest. The Act also assists decision-makers in adjudicating areas of custody, and so forth. The terminology of "the child" started to emerge as a judicial language. ${ }^{12}$

Hence, the establishment of a Children's Court, to protect the interests of the child on divorce. The Children's Court provides an impetus to continue to reflect on important legal decisions affecting children. Such a Court enables children to participate in Court procedures that will effect important decision-making about their future. Now that children have received this new legal capacity they could aired their voices and is no longer be seen as passive objects as has been in the past. ${ }^{13}$

\section{THEMES OF CUSTODY DECISIONS ON DIVORCED AND THE COMPLEMENTARY ROLE OF THE OFFICE OF THE FAMILY ADVOCATE}

Although the study has down-play biological parenthood against psychological parenthood, it premises in this context is on biological parenthood. In societal norms and practices, biological parenthood is seen as social parenthood. So much so that arrangements for child-care beyond the nuclear biological family are seen as potentially deficient and a substitute for natural care. Care for minor children connotes to biological parental care in most instances. ${ }^{14}$

\footnotetext{
77 Wright 2009: 5.

${ }^{8}$ Sandra Burman, Carmel Matthias et al. Introductory Chapter: Beyond the Rights of the Child. In: Sandra Burman (Ed). 2003. The Fate of the Child. Legal Decisions on Children in the New South Africa. First Edition. Juta Law, Lansdowne,

Cape Town: 2.

${ }^{9}$ Burman and Matthias 2003: 3.

${ }^{10}$ Burman and Matthias 2003: 3.

11 Burman and Matthias 2003: 3.

12 Burman and Matthias 2003: 4.

13 Burman and Matthias 2003: 6.

${ }^{14}$ Patricia C Henderson. Chapter 1: Questions on Fostering: An Anthropologist's Perspective. In: Sandra Burman (Ed). 2003. The Fate of the Child. Legal Decisions on Children in the New South Africa: 9.
} 
Within the ambit of divorce, Courts task themselves with the responsibility to uphold the "best interests" of children under their jurisdiction. ${ }^{15}$ They are not actually or materially involved in the care of minor children, but directed, for purposes or assistance, this obligation unto or towards responsible parents' or other institutions, such as the Family Advocate's Office, that are mandated legally to do so. Divorce battles seem to be onerous and impact negatively as well on the emotional and social lives of children. In other words children are scathed by the effects or aftermaths of divorces. As children are the powerless victims of divorce, provisions for their protection have to be implemented by High Courts as upper guardian of minor children. These courts ensure that the best arrangements are made for children in divorce instances. In support of to the High Courts, children's best interests are also protected by statutes, like The Children's Act of 1960, which was replaced by the Child Care Act 74 of 1983, and the Matrimonial Affairs Act 37 of 1953. These protective mechanisms eventually culminated in Section 28 of the Constitution of the Republic of South Africa Act 108 of 1996 and the Office of the Family Advocate, which was established in terms of the Mediation in Certain Divorce Matters Act 24 of 1987. These safeguards engineered for the best interests of the child served as a catalyst for the unsatisfactory manner in which divorces were finalised without regard to the needs of children in the past. ${ }^{16}$ The well-being of minor children was initially undermined. It often happened in both un-defended or settled cases. The Courts are not always given a complete overview of the real problems or details of the circumstances surrounding the breakdown of the marriage by lawyers or other professionals. Reasons that leading to settlement agreements were usually not disclosed. The supervision, custody and maintenance of the minor children are arranged by agreement of the parties. It is virtually impossible for the Court to satisfy itself that the arrangements made in such an agreement are in fact in the best interests of the minor children. ${ }^{17}$

The Office of the Family Advocate and the High Court's objectives are design to serve the best interests of the child. At first glance it would appear that these two institution's functions might overlap, but it is not the case. The former would never usurp the role of the latter as upper guardian of minor children. Their roles are rather complementary to each other. The function of the Office of the Family Advocate is to serve as an additional instrument or aid to the High Court. The Family Advocate is to provide the court with the guidance of an expert necessary to enable the judge or presiding officer to ensure that the best interests of the child is met. ${ }^{18}$ This office would ensure that the children's interests are not subordinated to those of their parents. ${ }^{19}$

\section{THE BASIS ON WHICH CUSTODY DECISIONS ARE MADE}

\section{(a) Child's Developmental Needs}

The basis on which custody decisions are made is an important area of study. The child's best interests must ultimately underpin all decisions. Little research has been conducted in South Africa and even fewer in Botswana on child custody evaluation practices. This study represents an effort to develop a Botswana model for custody in divorce matters. Factors that might impact on custody in divorce matters and which might take consideration of the child's developmental needs are the quality of the parental relationship, the parenting capacity of the custodian and socioeconomic status, the parent's moral character and identification with the primary care-giver. ${ }^{20}$ These factors will demonstrate that the child's basic developmental needs are more important than the parent's socio-economic resources. ${ }^{21}$ It appears that the author, Africa et al wants to stress that a child's developmental needs are to be aligned with the parent's ability to care appropriately for the child. The parental involvement criteria seem to be an important factor of a child's developmental needs. The parent who is the primary care-giver is going to be favoured. The criteria for the child's developmental need materialise into the consideration of his/her tender years. For example, it is to belief that a female adolescent needs maternal guidance. In most instances a female parent is regarded as more attuned to a young girl's developmental stage. ${ }^{22}$

A child's basic developmental need also include a reflection on the characteristics of the parents. A parent's history is an important consideration for post - divorce arrangements. Factors such as a parent's childhood history, his or her history of drug or alcohol dependence and the parent's capacity to contribute to the child's moral development are taken into consideration. Contrary to the notion that a parent's socio-economic status is not so important, Courts, nevertheless, pay attention to these factors. The provision for a sufficient infrastructure by the parent for the child is welcomed. ${ }^{23}$

\section{(b) Wishes Of The Child}

\footnotetext{
${ }^{15}$ Henderson Chapter 1: 31.

${ }^{16}$ Henderson chapter 1: 108-9.

${ }^{17}$ Henderson chapter 1: 109.

${ }^{18}$ Henderson chapter 1: 111.

${ }^{19}$ Henderson chapter 1: 115.
}

${ }^{20}$ Adelene Africa et et al. Chapter 6. Criteria Used by Family Counsellors in Child Custody Cases: A Psychological Viewpoint. In Sandra Burman (Ed). The Fate of the Child: 123.

${ }^{21}$ Africa et al chapter 6: 124.

${ }^{22}$ Africa et al chapter 6: 134.

${ }^{23}$ Africa et al chapter 6: 135. 
A wish of a child connotes to a preferred custody arrangement. A child's wishes seem to be accentuated by the Courts, professionals and counsellors when it concerns recommendations for maternal custody allocations. This view, however, is impacted on the notion that most young children cannot make decisions on their own and need someone to do it for them. Such sentiment stems from case law, McCall $v$ McCalR4, in which the Courts pay mere lip-service to the wishes of the child. The rationale that Courts did not regard the wishes of the child as serious connotes to the fact that their age might have something to do with it. Africa et al who might have showed a penchant for a reduced wish of the child, say it is practical not to pay too much attention to their preferences. ${ }^{25}$ The functionality of this sentiment is to be appreciated under the following narrative. While the child's opinion was sought, her or his opinion was not considered to be the determining factor for maternal custody arrangement. To relate the narrative, a ten-year-old girl said to the counsellor that she loves both parents and enjoys the time spent with her father. She, however, express her view that she want to live with her mother. An explication of the primary criteria on which the counsellor's decision regarding placement of the child is based, will now be presented. A report related that the father was the applicant for sole custody of a child. The father said he was forced to seek custody because of the mother's drug problem. In a joint interview conducted with the parents, the mother did not pitched during a follow up meeting. Given the mother's drug problem, it is noted that her drug abuse impacted negatively on her care-taking ability. In this case, the child's wishes towards a preference for replacement with her mother would likely seem to be suppressed, and rightly so. It is evident that the father is proving to be providing a secure, safe and emotionally protected environment to the minor child. Sole custody and guardianship is therefore be awarded to the father despite of the minor daughter's wish to be placed in the care of her mother. ${ }^{26}$

In not getting the full support and appreciation of counsellors and perhaps the judiciary, the Convention on the Rights of the Child (1995) wants to make up for this lack of understanding by serving as a platform for children to have their voices be heard and their wishes to be respected in matters affecting them. ${ }^{27} \mathrm{~A}$ child's right to air her voice or to make his or her wishes known is enshrined in the United Nations Convention on the Rights of the Child (1989). South Africa and Botswana are signatories to the UN Convention and are bound to the directives stipulates in the document when the wishes and rights of the child takes centre stage. The child's right to express his or her wishes and to participate in decisions that affect them, is beckoning increase attention from Courts. Since 1994, the Courts have shown an increase willingness to consider the wishes of the children when making custody decisions. The list of factors enshrined in McCall serves as a guiding mechanism for Courts. ${ }^{28}$ Tantamount to the Court's willingness after 1994 to acknowledge the child's wishes, article 12 (1) of the United Nations Convention of the Rights of the Child (1989) gives the child a right to be heard contingent upon the fact that the child is capable of forming his own views. The view of the child be given due weight in accordance with the age and maturity of the child. It entails that the expressed wishes of the child be overridden should his/her choice in a particular instance be deemed unwise. South Africa has ratified the UN Convention in 1995 and article 12 has not yet been incorporated into the country's divorce laws. Despite the matter of non-domestication of article 12, the age and maturity of the child should been the determining factor to accommodate the wishes of the child in divorce issues according to Justice Van Heerden in citing McCall v McCall at 207H-J. Judge Van Heerden concluded by saying that the Court should give serious consideration to the child's expressed preference and not lightly gives an order which overrides this. The South African divorce law seen Van Heerden's decision in McCall as locus classicus and would render henceforth that custody decisions must always be in the best interests of the child and that the wishes of the child should take centre stage. ${ }^{29}$

\section{(i) Difficulties Of Executing The Wishes Of Children}

The Lubbe judgment highlighted the procedural problems relating to the executing of the best wishes of the child. These problems are manifested by judicial interviews and courtroom testimonies, which hindered children to fully express their views. The Court room set-up is obviously intimidated towards children and judges usually lack the skills to put them at ease. Lawyers also fall short at the requisite interview and interpreting skills. This scenario does not provide a conducive environment to accommodate a child's voice. Not many cases reach the Courts. In other words the vast majority of children's wishes to be aired in Courts are left out of the equation. In order to promote the wishes of the child, and by shield the rights of the child from the ineptitude of Court officials, professionals like private psychologists or social worker's service was brought in to assist the Courts with regard to the expression of the best wishes of the child. But, invoking the services of these professionals is rather costly and thus accessible mainly for the affluent. Although the Family Advocate Office seems to be the logical setting for children to express their views, this state entity or institution is rather under-resourced and poorly funded. The Office of the Family Advocate is thus able to investigate only a small percentage of divorce cases, because some of the staff are insufficiently trained and does not have the requisite skills to actuate the wishes of the child. ${ }^{30}$

\footnotetext{
241994 (3) SA 201 (C).

${ }^{25}$ Africa et al chapter 6: 141.

${ }^{27}$ Africa et al chapter 6: 141. Fate of the Child: 148.

${ }^{29}$ Amanda Barraat chapter 7: 149.

${ }^{30}$ Amanda Barraat chapter 7: 156.
}

${ }^{26}$ Stahl, P.M. 1994. Conducting Child Custody Evaluations: A Comprehensive Guide. Thousand Oaks, California. Sage Publications, In: Africa et al, chapter 6: 136-37.

${ }^{28}$ Amanda Barratt. Chapter 7. The Best Interest of the Child - Where is the Child's Voice? In Sandra Burman (Ed). The 


\section{BEST INTERESTS OF THE CHILD}

\section{South Africa}

Where and with whom children should reside after their parent's divorce have an impact on the children concerned. Courts see it as their duties and responsibilities to focus primarily on the best interest of the child. The legislature, when it enacted The South African Divorce Act 70 of 1979, is premised on the same logic. This legislative imperative finds congruence with Section 28(3) of the Constitution of the Republic of South Africa (supra). This section provides that a child's best interests are of paramount importance in every matter concerning the child. Both this statute law and the Constitution is, however, not clear as to what encompasses the best interests criteria of the child. The criteria are subsequently illuminated by case law. Case law, McCall v McCall, ${ }^{31}$ supported by French $v$ French ${ }^{32}$ provided a useful checklist of factors of what the best interests of the child entail.

The Appellate Division held in Fletcher $v$ Fletcher ${ }^{33}$ that in matters of custody and access issues, the rights of the parents have to succumb to the best interests of the child. The principle, the best interest of the child has been entrenched by the South African Constitution (supra) under Section 28(2). The phrase is, however, not accepted without difficulties. There is thus a need for a determinate standard and the Courts are tasked to come up with a solution for its implementation. Fortunately the phrase is also used by the Children's Convention (supra) as well as the OAU Charter on the Rights of the Child. Article 3 of the Children's Convention provides:

In all actions concerning children, whether undertaken by public or private social welfare institutions, Courts of law, administrative authorities or legislative bodies, the best interests of the child shall be primary consideration.

ii. States Parties undertake to ensure the child such protection and care as is necessary for his or her wellbeing, taking into account the rights and duties of his or her parents, legal guardians, or other individuals legally responsible for him or her, and, to this end, shall take all appropriate legislative and administrative measures.

iii. States Parties shall ensure that the institutions, services and facilities responsible for the care or protection of children conform with the standards established by competent authorities, particularly in the areas of safety, health, in the number and suitability of their staff, as well as competent supervision. ${ }^{34}$

South Africa corroborates on its international exposure by domesticated the Hague Convention on the Civil Aspects of International Child Abduction Act 72 of 1996. This Act seeks to articulate the child's best interest by ensuring that custody and access disputes are adjudicated by Courts.

\section{(a) Difficulties In Implementing Best Interests Of The Child Standard}

As noted earlier in the text, children are not comfortable to express themselves sufficiently and freely on Courts. Thus, the establishment of a child-friendly Court in which court adjudicators can be able to hear, understand and give weight to what children in court are trying to say. These sentiments are also accommodated in the wording of article 12(1) of the 1989 UN Convention and article 4(2) of the 1990 African Charter.

The main reasons why children feel afraid and intimidated in Court stem from cultural and language differences between children and Court staff. This has a negative effect on the materialisation of the best interests of the child. In multi-cultural societies such as South Africa and Botswana children are expected to engage with Court staff whose cultural affiliations and/ or language familiarity are different from their own. This connotes to a language and cultural

${ }^{31} 1994$ (3) SA 201 (C). The factors that constitute the best interest of the child [at 204I/J-205G] are: (a) the love, affection and other emotional ties which exist between parent and child and the parent's compatibility with the child; (b) the capabilities, character and temperament of the parent and the impact thereof on the child's needs and desires; (c) the ability of the parent to communicate with the child and the parent's insight into, understanding of and sensitivity to the child's feelings; (d) the capacity and disposition of the parent to give the child the guidance which he requires; (e ) the ability of the parent to provide for the basic physical needs of the child, the so-called 'creature comforts,' such as food, clothing, housing and the other material needs - generally speaking, the provision of economic security; ( $f$ ) the ability of the parent to provide for the educational well-being and security of the child, both religious and secular; (g) the ability of the parent to provide for the child's emotional, psychological, cultural and environmental development; ( $h$ ) the mental and physical health and moral fitness of the parent; (i) the stability or otherwise of the child's existing environment, having regard to the desirability of maintaining the status quo; (j) the desirability or otherwise of keeping siblings together; $(k)$ the child's preference, if the Court is satisfied that in the particular circumstances the child's preference should be taken into consideration; ( $I$ ) the desirability or otherwise of applying the doctrine of same sex matching; $(\mathrm{m})$ any other factor which is relevant to the particular case with which the Court is concerned.

321971 (4) SA $298(W)$, at $299 \mathrm{H}$.

331948 (1) SA 130 (A).

${ }^{34}$ Iain Currie \& Johan de Waal. 2005. The Bill of Rights Handbook. Fifth Edition. Juta and Company Itd Lansdowne: 618. 
barrier phenomenon. This phenomenon inhibits children to speak out in Court and thus trample on their right to exert their best interests and wishes. The problematic aspects of language and cultural difficulties can be explicated in the following narrative: An individual, who was an advocate fluent in Zulu, asserted that where child witnesses appear, it is important that Court staff have appropriate cultural and linguistic understanding because children are frequently unable to present evidence as clearly or in the same logical consequence as adults. Another individual who is a magistrate asserted that black children who have been brought up to be respectful of elders and superiors are not to contradict statements made by them. ${ }^{35}$

Language and cultural differences not only affect how children feel and react in Court, they also make it more difficult for adjudicators to reach the correct decision at the end of the hearing. This averment indicates that there is a cultural and linguistic barrier that adversely affects children who appear in Courts. It is therefore essential that steps be taken in order to reduce cultural and linguistic dissonance in Courts. This suggestion is imperative in bringing the best interests of the child in line with the safeguard measure as prescribed by Section 28(2) of the South African Constitution.

\section{NARRATIVES OR CASE LAWS APPLICATIONS OF THE BEST INTERESTS OF THE CHILD IN RESPECT OF THE BOTSWANA JUDICATURE}

\section{(i) Unwed Father}

In the matter of Geofrey Khwarae $v$ The Attorney General, ${ }^{36}$ Khwarae is the biological father of a female minor, called Chedza. There was a brief romantic relationship between Kwarae (the applicant-father) and first responded, the mother of Chedza. Chedza's parents were not married at the time of her conception, nor at the time of her birth. Kwarae has played an active role in his daughter's life, including providing care and support during the first respondent's (mother) pregnancy and following the child's birth. ${ }^{37}$

Kwarae went to Norway to further his studies. His wife agreed to be available to attend to the child's needs. The child's mother was informed and understood the arrangement. Upon Kwarae's return to Botswana in 2006, he reconnected with the child and continued to support her. During a rough time in the life of the mother of the child, she led the child stayed with Kwarae from 2007 and the latter enrolled the child in an English Medium School. Kwarae arranged that the child visit her mother during the holidays on his expense. ${ }^{38}$

The boyfriend to Chedza's mother (third respondent) had in the meantime threatened to kill the child and was warned by the police. The mother subsequently demanded that the child stayed with her and her boyfriend. Shortly thereafter, the mother's sister contacted Kwarae and alleged that the mother of the child had abandoned the child after an argument with her boyfriend. ${ }^{39}$

It was then that Kwarae moved into action and applied for shared custody of the child in Court. The child, however, had expressed preference to stay with her mother (principle of the wishes of the child noted earlier in the text). The Court ordered therefore that the child should stay with the mother and granted visitation rights to Kwarae. Kwarae averred thereafter that he was denied access to the child and has not been permitted to see her despite the court order. Kwarae feared that the child would have been adopted by the mother's boyfriend without his consent.

Kwarae set out to make a case that the wording and implications of Section 4(2)(d)(i) of the Adoption of Children Act (Cap 28:01) seems to discriminate against him because of the fact that the said child was born out of wedlock. Kwarae also alleged that the same statute law (Adoption of Children Act (supra)) would rather entertain adoption procedures in favour of the child's mother's boyfriend. Kwarae averred that the exclusion of his consent as biological father with regard to the adoption of his child discriminates unjustifiably against him on the basis of his sex and marital status, in violation of Section 15 of the Constitution of Botswana. It is clear from these narratives that Kwarae is subjected to differential treatment because he was not married to the child's mother. The differential treatment meted out to unmarried fathers under Section $4(2)(d)(i)$ of the Adoption of Children Act, is irrational and unfair in that it allows for the unilateral termination of the rights and duties of biological fathers. This entrenches a view which is contrary to the best interest of the child, namely that fathers should have less attachment towards their children, particularly when not married. ${ }^{40}$ The effect of denying unmarried fathers a legally protected relationship with their children is to discriminate unfairly against them on the basis of their sex and marital status. The applicant (Kwarae) also complained that Section $4(2)$ (d) (i) violates his right to a fair hearing to the extent that it does not require his consent for the adoption of his child. He says that this denial violates Section 10(9) of the Constitution of Botswana.

The Attorney General opposed Kwarae's application for joint custody of his minor child. The Attorney General mentioned that Section 15(3) of the Constitution of Botswana was not violated because Kwarae perceived himself as an unmarried man and automatically deduced that he was discriminated against. The Attorney General noted that the

\footnotetext{
${ }^{35}$ Noel Zaal. Chapter 8. Hearing the Voices of Children in Court: A Field Study and Evaluation. In: Sandra Burman (ed). The Fate of the Child. Legal Decisions on Children in the New South Africa. First edition. Juta: 163.

${ }^{36}$ MAHGB-000291-14.

${ }^{37}$ Kwarae case, paras 8-11.

${ }^{38}$ Kware, paras 11-16.

${ }^{39}$ Kwarae, paras 17-19.

${ }^{40}$ Kwarae [34].
} 
description of Kwarae as an unmarried man relates to social standing and not to any of those grounds mentioned in Section 15(3) of the Botswana Constitution. ${ }^{41}$ The Attorney General took us through both the common law as well as the customary laws of Botswana. This was aimed in order to make one understand the rationale and justification behind Section 4(2)(d)(i) of the Adoption of Children Act (supra). The Attorney General argued that in terms of our customary law, a child born out of wedlock belongs to the mother's family. In terms of customary law, the father of a child born out of wedlock has no legal rights over the child due to the surreptitious nature of conception. ${ }^{42}$ The position has now changed through various legislative instruments which see the biological father being recognised as the father of the child, although his rights are only limited to the best interests of the child in so far as upbringing is concerned. According to the Attorney General, the biological father acquires a limited right to be consulted only where the biological father has been actively involved in the child's life from the beginning. ${ }^{43}$

The Adoption Act states that if the child is adopted, the consequences thereof would be to terminate the rights of the biological father.

The Children Act of 2009 recognises the unmarried father as a parent and acknowledges that there is a relationship between him and his offspring. The Children Act suggests that biological fathers hold protected rights regarding the parent-child relationship, especially as seen from the perspective of the child and their best interests, which are to be considered paramount in all decisions concerning children. The Children Act does not distinguish on the basis of marital status of the parent(s). ${ }^{44}$ The Children Act has established that the unmarried father may no longer be excluded from the legal definition of "parent" and must participate in legal proceedings concerning the future of his child. Section 28 of the Act defines the rights of every parent vis-à-vis the best interests of the child as the right to have the child live with them; the right to be involved in the child's upbringing; and the right to participate in Court and other proceedings relating to his child. ${ }^{45}$

In the Kwarae-case, the judges cited international jurisprudence regarding custody issues as per Lehr $v$ Robertson ${ }^{46}$ as interpreted in Stanley $v$ Illinois, and Caban v Mohammed. The Court demonstrated in these cited case laws a paramount inclination towards parental interest by a parent in contradistinction to biological parenthood. The Court went on to say, when an unwed father shows a full commitment to the responsibilities of parenthood, his interest in personal contact with his child acquires substantial protection under the Due Process Clause. The mere existence of a biological link does not merit equivalent constitutional protection. ${ }^{47}$ But the implications of biological connection have its merits. Biological connection offers the natural father an opportunity that no other male possesses to develop a relationship with his offspring. And no Court ought to deny the development of that relationship where the unwed father has consistently shown that he cares for his child. ${ }^{48}$ It is this parent-child bond that deserves constitutional protection. The level of the biological father's commitment determines where the best interest of the child lies. ${ }^{49}$

The primary standard to be applied in all questions of guardianship or access to children, whether parents are married or unmarried, is that of the best interests of the child..$^{50}$ The illegitimacy of the child is not the compelling reason for denying access by its father. It is the interest of the child which must preponderate rather. ${ }^{51}$ In the present case (Kwarae), it is clear that the applicant, Kwarae had cultivated a close relationship with his child and contributed substantially to her education and general welfare. His interest in the welfare of his child was not sporadic, but consistent over time..$^{2}$ Amid dictates of Customary law and relics of English Common and Roman-Dutch law about child adoption by an unmarried father, the Court noted what matters most is the best interests of the child. ${ }^{53}$ The Court therefore ordered that Section 4(2)(d)(i) of the Adoption of Children Act is unconstitutional to the extent that it does not require the consent of the father in the adoption of his illegitimate child. The Court also ruled that any adoption of the minor child can only be done with the consent of the applicant, Kwarae and that any adoption of the child without his consent is rescinded henceforth.

\section{(ii) Careless Mother}

In Muyle $v$ Mmutle ${ }^{54}$ the parties contested the custody of their minor son. A divorce order was granted upon the irretrievable breakdown of the marriage between them. The defendant (wife/mother) had behaved in such a manner that the plaintiff (husband/father) could not reasonable be expected to continue living with her. Some of the particulars

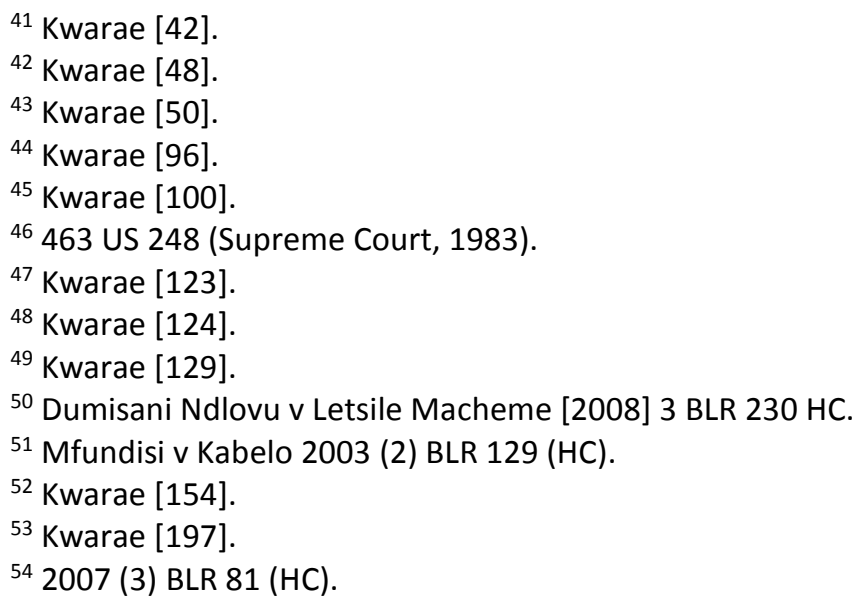


of the defendant-wife's alleged behaviour were that she has a violent temperament, suicidal tendencies, drank excessively and did not give the minor child love and care. A settlement agreement was entered into by plaintiffhusband and dependant-mother, whereby the mother wanted custody to be awarded to her. It was very odd, in the light of the allegations that were presented to Court, which rendered the mother unsuitable. The Court as upper guardian of all minor children, have the discretion to question an agreement on custody where it is doubtful if the agreement is in the child's best interest. The Court as a result ruled upon an interim order that the child for the time being remained with the mother. The reason for this verdict by the Court was that the child was in fact staying with the mother's grandparents - and not with his mother. The father complained that the defendant's parents were denying him reasonable access to the minor child on the excuse that they were acting at the mother's behest. ${ }^{55}$

The Court interpreted the mother's failure to turn up for hearing on two occasions in a matter so important for the future of her minor child as evidence of her carelessness. The father claimed that the welfare of the minor child will be best served if custody is awarded to him in that he will be able to give the child a comfortable and secure home. He also intended to give the child a good education. At the time of the hearing, the child who stayed with the mother's parents had not been sent to pre-school at Francistown. The father committed himself to secure a place for the child at an English Medium School where he had been previously paying school fees. The father also attended a parenting skill course in Gaborone, called Child Line Botswana, and a certificate of completion was awarded to him. ${ }^{56}$

The mother, who has interim custody of the child, stayed in a two bedroom house and could avail adequate accommodation to the child. The child, however, is staying hundreds of kilometres away from her, under the care of her parents. The Court echoed the question, when does she give the child that parental love, nurture and guidance that is expected of a natural parent. As mentioned earlier, the mother has not even come to Court to deal with the serious allegations made by the plaintiff in his declaration for the custody of the child. These allegations impact negatively on her as she was not available to traverse them. And the Court would have likely take the position that she might not be the right person for custody entitlement arrangement of the minor child. ${ }^{57}$

In this hotch-potch of contradictory evidences between the parties, the court let itself being guided by one predominant consideration, the best interest of the child. The court took note thereof that the mother's conduct has a negative bearing or impact on her suitability for an award of custody of the minor child. The child still under interim custody of the mother had not been physically under her care despite that fact that she has adequate accommodation to provide the child with. Mention was also made about her temperament and excessive drinking habits. The concept of the best interest of the child is designed to ensure that custody will be awarded to a parent who can best provide the child with an upbringing in a stable and secure environment to equip the child with the necessary emotional, educational, moral and material tools for a balanced adult life..$^{58}$

In this case, the father appears to be the ideal person to whom custody should be awarded - if the best interest of the child is to be perceived or regarded as the primary principle. The father undertook to the court that he will ensure that the child maintains its contacts with its grandparents and will promote access of the mother to the child.

\section{(iii) Desirability Of Keeping Siblings Together/ The Principle Of Indivisibility}

In Mazile $v$ Mazile ${ }^{59}$ the applicant, mother of two boys ages two and one, took them with her to Gaborone to establish a new home for them. She managed to found a low cost home comprises with water, electricity and a telephone. The respondent, the father of the boys remained in Makoro, his place of residence. The respondent manages and runs the businesses of his parents. He used to make regular visits to Serowe, the family home. His intention is to make Makoro the main home for himself and the boys. At Makoro, the respondent lives with his mother and about 15 workers in one compound. The mother lives in a house with electricity, water and a telephone. The respondent lives in a nearby rondavel which has none of the above mentioned facilities. He has, however, access to the facilities of the main house where his mother lives.

Around December 2000, the applicant-mother took the two boys to Serowe. The conflict between the parties arose when the applicant sought to take the children back to Gaborone and the respondent-father insisted they remain in Serowe. The applicant seeks an order granting her custody. She intended to move back to Gaborone where she is engaged in a part-time job and her wishes to further her studies. The respondent, who has initially sought custody of the two boys, have changed his tune and now seeks the custody of the older boy only. His proposal amounted to a separation of the two boys. ${ }^{60}$

The court determines now who of the two parents should be granted custody - and asserted that the best interest of the child should be the determining factor. The court brought into account the following factors for determination of custody of the two boys. First is the factor of the suitability of the parent. It is the opinion of the court that weighing up

\footnotetext{
${ }^{55}$ Mmutle, p. 83.

${ }^{56}$ Mmutle, p. 84.

${ }^{57}$ Mmutle, p. 85.

58 Mmutle, p. 85.

592001 (1) BLR 175 (HC).

${ }^{60}$ Mzile v Mazile, p. 176.
}

http://www.elaws.gov.bw/Irfrm.php?words=Enter $+a+k e y w o r d \& x=21 \& y=13 \& t a b=2 \&$ chk1=checkbox Accessed

21/03/2017 (page 1 of 3). 
the testimonies or affidavits of the parents who is/are to have maximum possible contact with the parents. The second factor which is about the desirability of keeping siblings together. The respondent-father move to have custody of both boys' has been overturned by him and he wants custody of only the elder boy. This manoeuvre amounts to the fact that the two boys will now have to be shared between the parties. Such an action amounts to what is called in the Mokoti $v$ Okatswa ${ }^{61}$ (infra) the principle of indivisibility which stands in contrast to the best interests of the child standard. Indivisibility is at times equated with the best interests of the child. Separation would not be in the best interests of the child. The third factor is the availability of the parent to provide day to day care facilities to the minor children. The most hands-on person in this regard seems to be the mother. The nature of the father's work is such that he is not involved in domestic matters. He shuttles between his two main residences and even travelled further afar to attend to business errands. This made him less available to provide intimate day to day care of the two young boys'. The children have been left in the care of the respondent's 78-year old father. It is evident that should the father be awarded the custody of the two boys, he would have to enlist the help of others to provide for the boys' day to day care. The fourth factor is the desirability of ensuring stability and security in the lives of the children. The father's plan to remove the children to Makoro so that his mother can care for them is little far-fetched. These plans cannot successfully compete with the applicant's clear plans of keeping the children at the Gaborone plot. The mother's plans showed constancy. The father, due to his business commitments, will not be a constant in the boys' lives. The mother, on what is postulated here, is clearly the best suited candidate for custody of the children than the respondent. ${ }^{62}$

The court therefore awarded custody to the applicant-mother with visitation rights granted to the respondent-father.

\section{(iv) The Effect Of III-conduct Of A Mother Towards Court Procedure In Custody Matter}

In Phibion v Phibion ${ }^{63}$ a decree nisi for divorce in favour of the plaintiff-mother was made final and the court ordered that social welfare reports relating to the custody of the sole minor child be produced for it to adjudicate on. At the time of the divorce the child was in the care of his defendant-father since he was two months. The plaintiff-mother has reasonable access to the child. The mother decided not to return the child to the father. ${ }^{64}$ This case law became the subject of litigation between the parents on the issue of custody over the minor child. In the course of the court litigation, the mother failed to turn up on two different occasions regarding the custody matter. Justice Collins has this to say about her ill-conduct: "Her conduct displays disdain for the court and a complete lack of seriousness about such an important matter [custody of the child]." 65 This line of thought reverberates the same sentiment echoed by Justice Lesetedi in Mmutle v Mmutle (supra), where the Judge held that a party's conduct has a bearing on his or her suitability for an award of custody of minor children. ${ }^{66}$ This line of thought is exactly what sank the mother in her petition for custody of the minor child. The court, upon the poor interest of the mother regarded the father to be a fit and proper person to be awarded custody of the minor child. The court ruled liked in the Mazile $v$ Mazile (supra) case that the plaintiff be granted reasonable access to the child. By these similarities featuring between the two paraphrasing, both Mazile and Phibion case laws adhered to the legal principle of indivisibility with regard to custody issues of minor children.

\section{(v) Mother Turned Child Against The Father}

In Modisenyane $v$ Modisenyane ${ }^{67}$ the relationship between the parties has deteriorated from the time of their marriage on 27 July 2000. Two children, who were minors at the date of trial, were begotten from the marriage. The applicantfather in the matter was granted an order by the court to have rights of access to their minor children. The respondent-wife, in defiance of the court order, refused to allow the applicant to visit the children. Justice Chinhengo stated that the conduct of a parent who deliberately attempts to turn a child against the other parent or by demonstrating hostility towards the other parent or frustrating contact between the child, such parent is prejudicial to the child. ${ }^{68}$ In the present case, the mother has sought to alienate the children's affections for the father by frustrating contact with him.

It is also important that court orders should be complied with. The father alleged that he attempted on two occasions to take the children with him in terms of a court order. On both occasions the mother frustrated him to do so. She was therefore in contempt of court and a fine was imposed upon her as sanction for the crime. The court however reserved its decision with regard to custody awarding on the basis that the divorce proceedings are still pending. It, however, ruled that the father is entitled of access rights to the children and if the mother disturbed the order, then the fine (which had been suspended) will have to kick in. As for now the fine is in suspension upon her behaving herself accordingly. The mother is also ordered to pay applicant's costs on the scale as between attorney and client.

\footnotetext{
6120112 BLR 1021 (HC).

62 Mazile, p. 178.

632000 (1) BLR 195 (HC).

${ }^{64}$ www.elaws.gov.bw/Irfrm.php?words=Enter+a+keyword\&x=21\&y=13\&tab=2\&chk1=checkbox .Accessed 22/02/2017.

${ }^{65}$ www.elaws.gov.bw/Irfrm.php?words=Enter+a+keyword\&x=21\&y=13\&tab=2\&chk1=checkbox .Accessed 22/02/2017.

66 http://elaws.gov.bw.desplaylrpage.php?id=3488\&dsp=2. Accessed 22/03/2017.

672006 (2) BLR 65 (HC).

${ }^{68}$ www.elaws.gov.bw/Irfrm.php?words=Enter+a+keyword\&x=37\&y=8\&tab=2\&chk1=checkbox. Access on 22/03/2017.
} 


\section{(vi) Develop The Common Law In Respect Of The Values Of Constitutional Precepts}

In Mokoti $v$ Okatswa, ${ }^{69}$ the parties had lived together as man and wife for several years and had two children. The respondent-wife later moved out of the common home together with the children and married another man. The applicant-father also subsequently married. In the present application, the applicant opposed the lawful take-over of the children by their mother's new husband and sought continued interaction with them. After a consideration of the Roman Dutch authorities, local and international jurisprudence, the court held that the paramount consideration was the best interests of the children.

The Roman-Dutch legal principles on custody became obsolete and its legal authority null and void. It is in this atmosphere of invalidity that scholars tried to revive the interest in Roman-Dutch law by linking it with the values and prescripts of international human rights instruments. Coupled with international law instruments, Roman-Dutch law revealed a penchant towards the best interest of the child after casting off its erstwhile and out-dated legal enactments (as postulated earlier in the text). This manoeuvre was certainly actuated by the influence of constitutional dictates and the importance of international law instruments which are also beset with human rights values. For example, Article 3 of The United Nations Convention of the Rights of the Child (CRC) states that in all actions concerning children, whether undertaken by public or private social welfare institutions, courts of law, administrative bodies, the best interests of the child shall be the paramount consideration. The principle of the best interest of the child was domesticated through the promulgation of the Children's Act (Cap 28:04). Section 5 of the Act says a person or the court performing a function or exercising a power under this Act shall regard the best interest of the child as the paramount consideration. Judge Feetham in Cook v Cook ${ }^{70}$ stated at p. 134 of Fletcher v Fletcher (supra) that what is really at issue in all custody cases is the interest of the child. The primacy of the best interests of the child in custody cases is similarly acknowledged in the jurisprudence by Botswana case laws, as is evident in the study. An inclination towards constitutionalism is detected in the case of Macheme $v$ Ndlovu (supra) where it was held that the old rules had been abandoned in favour of the welfare of the child which attracted constitutional protection.

\section{CONSTITUTIONAL APPLICATION}

Almost similar to the Mokoti $v$ Okatswa case emerges the case law of Ndlovu $v$ Macheme. ${ }^{71}$ The judges in the Ndlovu case took recognition of the Mokoti case. They stressed that the courts have a duty to develop the common law. The judges realised that the Roman-Dutch law principles might be archaic, out of date and it might seems inconsistent with constitutional precepts. The Roman-Dutch law is perceived to conflict with the right to equality (father's right to his illegitimate child is regarded as lower than that of the mother of the same child under Roman-Dutch law), which is an important provision in the Constitution of Botswana. ${ }^{72}$ The provisions in the Constitution materialise under sections 3 and 15 of the Constitution of Botswana. The Constitution provides in section 3 that every person is entitled to the fundamental rights and freedoms of the individual. Amongst these rights and freedoms are the "protection of the law" by all, which must be applied to all with an equal imperative - to a father and mother of an illegitimate child, in particular and to legitimate children as well. In reverting to section 15 of the Constitution (which deals with discrimination), it has been argued that the word "discrimination" is not mentioned in section 3 , and therefore, is to be regarded as null and void. In other words, it does not mean that discrimination, in the sense of unequal treatment, is not proscribed under the section. Section 15, therefore does not confer an independent right standing on its own - it must be read in conjunction with section 3 of the Constitution of Botswana. The jurisprudence of the Botswana Courts makes it clear that discrimination based on sex is impermissible. ${ }^{73}$ In the light of these renditions, it is clear that Roman-Dutch law violates section 3, as read with section 15 of the Constitution to the extent that it affords irrational differential treatment between parents of a child simply on the ground of sex or marital status. To deny children access to their fathers because they are considered illegitimate is offensive to the spirit and letter of the Constitution. ${ }^{74}$

\section{CONCLUSION}

Within the climate of the Ndlovu $v$ Macheme and Mokoti $v$ Okatswa cases, the best interests of the child attracted constitutional limelight and elevated the interests of children above those of their parents. The latter's interests had held sway for centuries and the rights of children were subdued to a great extent. Botswana, who followed a RomanDutch and English common law tradition, was forced to submit to the dictates of these laws. It was only when a new constitutional dispensation came into effect after 1994 that the influence of a democracy crept into law and the creation of a new constitution in South Africa. Children are coming to benefit from such developmental structure.

This developmental path seemed to have an effect on Botswana as well. Seeing from the emergence of case laws such as Ndlovu v Macheme and Mokoti v Okatswa, where the imperative of constitutional authority took centre stage

\footnotetext{
6920122 BLR 1021 (HC).

701937 AD 154.

${ }^{71}$ [2008] 3 BLR 230.

72 Ndlovu v Macheme, para. $\mathrm{H}$. www.elwas.gov.bw/Irfrm.php?words=Enter+a+keyword\&x=37\&y=8\&tab=2\&chk1=checkbox. Access 23/03/2017.

${ }^{73}$ Attorney General v Dow.

${ }^{74}$ Ndlovu v Macheme, para $\mathrm{H}$.
} 


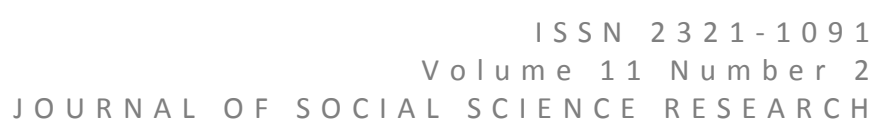

when it comes to the best interests of the child. These case laws of Botswana did away with the antique remnants of the Roman-Dutch and English common law, which have suppressed the rights of children and in particular the best interests of the child in custody and access issues upon divorce. Under a new spirit of the emancipation from erstwhile laws, the path for a modern interpretation is mapped out in which the values of the constitution could be sufficiently impacted on and uphold. The Ndlovu $v$ Macheme case serves as blueprint for such constitutional development. In this case it is demonstrated that when, for example, a father has shown sufficient degree of commitment to his child; that he is a responsible and genuinely wants his child to be part of his life, then the Courts will be convinced that the best interests of the child dictates that the father be granted access and even custody in spite of his unwed status.

To deny children access to their fathers because they are considered illegitimate is offensive to the spirit and letter of the Constitution of Botswana.

\section{REFERENCES}

Adelene Africa et al. Chapter 6. Criteria used by Family Counsellors in Child Custody Cases. A Psychological Viewpoint. In: Burman Sandra et al (Ed.). 2003. The Fate of the Child. Legal Decisions on Children in the New South Africa. First Edition. Juta Law, Lansdowne, Cape Town.

Adoption of Children Act (Cap 28:01).

African Charter (1990). OAU Doc. CAB/LEG/24.9/49, Monrovia, Libia.

Amanda Barratt. Chapter 7. The Best Interests of the Child - Where is the Child's Voice? In: Burman Sandra et al (Ed.). 2003. The Fate of the Child. Legal Decisions on Children in the New South Africa. First Edition. Juta Law, Lansdowne, Cape Town.

Attorney General v Dow (2001) AHRLR 99 (BwCA 1992).

Burman Sandra, Carmel Matthias et al (Ed.) Introductory Chapter: Beyond the Rights of the Child. In: Burman Sandra et al (Ed.). 2003. The Fate of the Child. Legal Decisions on Children in the New South Africa. First Edition. Juta Law, Lansdowne, Cape Town.

Caban v Mohammed 441 U.S. 380 (1979).

Constitution of the Republic of Botswana (1966).

Convention on the Rights of the Child (1995).

Cook v Cook 1937 AD 154.

Children's Act (1960).

Children Act (2009) (No. 8 of 2009).

Child Care Act 74 of 1983.

Currie, lan \& De Waal, Johan. 2005. The Bill of Rights Handbook. Fifth Edition. Juta and Company Ltd, Lansdowne.

Davids v Davids 1914 WR 142.

Dhanabakium v Subramaniam 1943 AD.

Dumisani Ndlovu v Letsile Macheme [2008] 3 BLR 230 (HC).

Fletcher v Fletcher 1948 (1) SA 130 AD.

French v French 1971 (4) SA 298 (W).

Geofrey Khwarae v The Attorney General MAHGB-000291-14.

Hague Convention on the Civil Aspects of International Child Abduction Act 72 of 1996.

Henderson, Patricia C. Chapter 1: Questions on Fostering. An Anthropologist's Perspective. In: Burman Sandra et al (Ed.). 2003. The Fate of the Child. Legal Decisions on Children in the New South Africa. First Edition. Juta Law, Lansdowne, Cape Town.

http://www.elaws.gov.bw//rfrm.php?words=Enter+a+keyword\&x=21\&y=13\&tab=2\&chk1=checkbox Accessed 21/03/2017 (page 1 of 3 )

http://elaws.gov.bw.desplaylrpage.php?id=3488\&dsp=2. Accessed 22/03/2017.

http://elaws.gov.bw/desplaylrpage.php?id=4592\&dsp=2. Access 21/03/2017.

Lehr v Robertson 463 US 248 (Supreme Court, 1983).

Macheme v Ndlovu [2009] 1 BLR 120 (CA).

Mazile v Mazile 2001 (1) BLR 175 (HC). 
Matrimonial Affairs Act 37 of 1953.

McCall v McCall 1994 (3) SA 201 (C ).

Mfundisi v Kabelo 2003 (2) BLR 129 (HC).

Modisenyane v Modisenyane 2006 (2) BLR 65 (HC).

Mokoti v Okatswa 2011 (2) BLR 1021 (HC).

Muyle v Mmutle 2007 (3) BLR 81 (HC).

Mediation in Certain Divorce Matters Act (Act 24 of 1987).

National Children's Rights Committee (NCRC), 1994.

OAU Charter on the Rights of the Child. OAU Doc. CAB/LEG/24.9/49 (1990).

Office of the Family Advocate (1990).

Phibion v Phibion 2000 (1) BLR 195 (HC).

South African Constitution, Act 108 of 1996.

Stahl PM. 1994. Conducting Child Custody Evaluations: A Comprehensive Guide. Thousand Oaks. California. Sage Publications. In: Adelene Africa et al. Chapter 6. Criteria used by Family Counsellors in Child Custody Cases. A Psychological Viewpoint. In: Burman Sandra et al (Ed.). 2003. The Fate of the Child. Legal Decisions on Children in the New South Africa. First Edition. Juta Law, Lansdowne, Cape Town.

Stanley v Illinois 405 U.S. 645, 92 S.Ct. 1208, 31 L. Ed 2d 551, 1972 U.S.

T v M 1997 (1) SA 54 (A).

The United Nations Convention of the Rights of the Child (CRC). OAU Doc. CAB/LEG/24.9/49 (1999).

United Nations Convention (1989). Adopted and opened for signature, ratification and accession by General Assembly resolution 44/25 of 20 November 1989, New York.

Wright, Ruth Ann. 2009. The Best-Interest of the Child Variables in Custody Evaluations and their Usefulness to the Decision-Making of Custody Evaluators, Litigants, and Judges. A Dissertation submitted to Fielding Graduate University in partial fulfilment of the requirements for the degree of Doctor of Philosophy in Psychology. Pro Quest LLC, Parkway, United States.

Zaal, Noel. Chapter 8. Hearing the Voices of Children in Court. A Field Study and Evaluation. In: Burman Sandra et al (Ed.). 2003. The Fate of the Child. Legal Decisions on Children in the New South Africa. First Edition. Juta Law, Lansdowne, Cape Town.

\section{AUTHOR BIOGRAPHY WITH PHOTO}

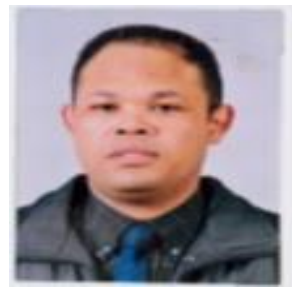

Dr Nico P. Swartz holds the following degrees: B. Proc., LL.B., LL.M (Cum Laude), LL.D., B.A. Honores (Latin), and M.A. (Latin).

Dr Swartz has published numerous scientific research articles for local and international journals. He has presented scientific papers, particularly in the exciting field of law, Islamic finance and banking, economics, theology, legal philosophy, Latin and human rights.

Dr Swartz is the author of eight books:

i. Historia Persecutionis: The Martyr Accounts of Victor of Vita.

ii. Rosmini's (1797-1855) Contribution to Theology, Philosophy and Fundamental Rights in Civil Society, According to Post-Thomist Natural Law.

iii. The Jurisprudential Implications of Thomas Aquinas's Political Science, with Specific Reference to the Form/matter and Soul/Body Notions that Culminate in the Church/State Relationship: A Philosophical Reflection.

iv. The Application of the Prohibition of Usury (Riba) in Islamic Finance and Banking Law: A Comparative Study.

v. 'n Kritiese Bespreking van Victor van Vita se Aanbieding van die Martelaarsverhale in die Historia Persecutionis vanuit ' $\mathrm{n}$ Historiese and Literere Perspektief.

vi. Lessons that need to be learned from the Global Financial Crisis. 
vii. In Defence of Human Rights: From the Womb to the Tomb.

viii. The Implications of Antonio Rosmini's Political and Social Philosophy on Fundamental Rights.

Dr Swartz is also, in terms of the Admission of Advocates Act, 1964 (Act 74 of 1964), permitted and authorised to practice as an advocate of the High Court of South Africa. He is currently employed by the University of Botswana.

cc) (i)

This work is licensed under a Creative Commons Attribution 4.0 International License.

DOI: $10.24297 /$ jssr.v11i2.6137 